\title{
Developed validation for simultaneous determination of three Di-caffeoylquinic acid derivatives from the Leaf of Eribotrya japonica Lindl. by HPLC-DAD
}

\author{
Ho-Young SEON ${ }^{1 ¥}$, Hyun-Hee KIM ${ }^{1 ¥}$, Soon-Ho YIM ${ }^{1 *}$ (ic
}

\begin{abstract}
The aim of this study was to developed HPLC simultaneous analysis method for the determination of Caffeoylquinic acid isolated from the leaf of Eribotrya japonica Lindl. extract. The phenolic compounds in E. japonica leaves were isolated and identified by HPLC, NMR, Mass etc. The quantitative analysis was carried out HPLC-DAD using C18 column with gradient elution of water and acetonitrile at $280 \mathrm{nM}$ for $60 \mathrm{~min}$. The method was successfully validated by specificity, LOD (linearity, limit of detection), LOQ (limit of quantification), precision and recovery. The three phenolic compounds were isolated from E. japonica leaves including 5-Caffeoylquinic acid (5-CQA), 4-Caffeoylquinic acid (4-CQA) and 3-Caffeoylquinic acid (3-CQA). In a quantitative analysis of three phenolic compounds were 3-CQA 7.82-14.48 $\mu \mathrm{g} / \mathrm{mL}, 4-C Q A ~ 3.75-12.58 \mu \mathrm{g} / \mathrm{mL}$ and 5-CQA $3.60-7.82 \mu \mathrm{g} / \mathrm{mL}$ using the standard chemicals, respectively. The developed HPLC validation method would be applicable for simultaneous quantitative analysis of phenolic compounds in $E$. japonica leaves extracts.
\end{abstract}

Keywords: validation; simultaneous analysis; 5-Caffeoylquinic acid; 3-Caffeoylquinic acid; 4-Caffeoylquinic acid.

Practical Application Validation development for product marker compounds selection and quality control.

\section{Introduction}

Eriobotrya japonica, also known as 'loquat', belongs to the Rosaceae evergreen species. The flower of this plant blooms from October to November and the leaves and fruits were harvested from May to July 5-7 of the following year (Ham et al., 2012). The plant originated in south-eastern China and later became naturalized in Korea, Japan and many other countries (Eom et al., 2009). Especially, the leaves of $E$. japonica have been widely used as a traditional medicine with beneficial effects as an expectorant, for hemoptysis, quenching thirst, chronic bronchitis, edema, septic settlement, and a strong stomach (Shin et al., 2012). According to recent study, it has been reported to be the effect of various component analyses (Bae et al., 2002; Bae et al., 2005), gastroenteritis improvement (Takuma et al., 2008), antioxidant (Hwang et al., 2010; Park et al., 2008; Jeong et al., 2009), anticancer (Kim et al., 2009c; Lee et al., 2004), antibacterial (Bae et al., 2002; Bae et al., 2005; Lee \& Kim, 2009), anti-inflammatory (Shin et al., 2012; Kim et al., 2009a; Banno et al., 2005), anti-diabetic (Kim et al., 2009b; Kim et al., 2006; Chen et al., 2008), skin whitening and skin allergy inhibition (Sun et al., 2007). Also, it has garnered attention in various herbal ingredients markets because it is safe and does not have side effects (Hwang et al., 2010; Lee et al., 2004). Therefore, this plant can be available in a wide range of alternative natural products which explore the utility for herbal ingredients and are highly valued commercially.
The main constituents of E. japonica have been reported various phytochemicals such as tannins, susquiterpene glycoside, megastigmane hlycosides, flavonoids, amygdalin, phenolics, procyanidin, triterpenic acid and triterpenoid (Kim et al., 2009d; Wu et al., 2018; Ito et al., 2000; Louati et al., 2003; Ding et al., 2001; Shih et al., 2010). Previous studies of triterpenoids and flavonoids on this plant have been focused on various biological activities such as anti-oxidant, anti-tumor, anti-viral and antiinflammatory activities (Lee et al., 2004; Whang et al., 1996; Lv et al., 2008). Moreover, Phenolic compounds which are representative secondary metabolite of the plant is known to be involved in various antioxidant activities. It is known that antioxidant activity depends on the content of the phenolic compound (Liu, 2004; Manach et al., 2005; Ryu et al., 2006). Especially, polyphenols such as chlorogenic acid contained in E. japonica leaves have a variety of physiological activities (Lee et al., 2004; Kim et al., 2009d). Recently, studies on antioxidant substances in order to eliminate ROS and RNS that increase or eliminate antioxidants of in vitro and in vivo have been conducted, and various bioactivity research such as anti-oxidant effects of natural products have been widely reported (Choi et al., 2003; Kim et al., 2008).

Herein we performed to the extraction availability of $E$. japonica leaves on different ethanol concentration extraction solvent were compared and analyzed. A major aim of this study 
was to extract, isolate, and identify phenolic compounds from E. japonica leaves using high performance liquid chromatography (HPLC), nuclear magnetic resonance (NMR), and mass spectrometry (MS).

Another aim is to describe developed the simultaneous determination using HPLC-DAD validation methods for the identification of the major phenolic compounds in E. japonica leaves extracts. Also, these results are to provide basic information for the quality standardization of phenolic compounds established by HPLC-DAD method from E. japonica leaves and development of natural antioxidants.

\section{Materials and methods}

\subsection{Plant materials}

The leaves of E. japonica were collected from the Goheung Loquat Farm in June 2016 and identified by Prof. Hyun-Jung Kim of the College of Pharmacy, Mokpo National University, Korea.

\subsection{Chemical and reagents}

The 5-Caffeoylquinic acid (5-CQA, 1), 3-Caffeoylquinic acid (3-CQA, 2) and 4-Caffeoylquinic acid (4-CQA, 3) were purchased from Sigma-Aldrich Company (St. Louis, MO, USA) as a standard chemical with a purity $98 \%$ purity.

\subsection{Instrument and reagents}

Nuclear Magnetic Resonance (NMR) was performed on a Varian unity Inova NMR spectrometer ${ }^{1} \mathrm{H}: 600 \mathrm{MHz}$ and ${ }^{13} \mathrm{C}: 151 \mathrm{MHz}$. Liquid chromatography-mass spectrometry (LC/MS) was measured on a LCQ Fleet LC-MS system (Thermo scientific) in negative and positive electrospray ion (ESI) modes. Analytical HPLC was performed on an Agilent 1100 series, which consists of a degasser, a binary mixing pump, a column oven and a PDA detector, using a SHISEIDO CAP CELL PAK $(4.6 \times 250 \mathrm{~mm}$, Tokyo, Japan $)$ column. Semi-preparative HPLC was carried out on a Waters 600E multi-solvent delivery system connected with a DECASSITTM 6342 degasser, using Atlantis $\mathrm{OBD}^{\mathrm{TM}}(19 \times 250 \mathrm{~mm}, 5 \mu \mathrm{m})$ columns. HPLC-grade solvents, acetonitrile and water were obtained from J. T. Baker (Phillipsburg, NJ, USA).

\subsection{Extraction and isolation}

The dried leaves of E. japonica ( $1.5 \mathrm{~kg}$ ) were extracted with water (15 L, $4 \mathrm{hr}$, three times) by Ultra High Speed Vacuum Low Temperature Extractors (COSMOS600-50L, Kyungseo Machines Co., Incheon, Korea) at $100^{\circ} \mathrm{C}$ and evaporated using a freezedryer at $-70^{\circ} \mathrm{C}(216.4 \mathrm{~g})$. The residue components was separated by repetitive Prep-HPLC cycles (Atlantis Prep T3 column, 5 um, $19 \times 250 \mathrm{~mm}$ ) by HPLC-PDA system (Waters, 600 system, USA) using a gradient of $0.1 \%(\mathrm{v} / \mathrm{v})$ formic acid in water (A) and acetonitrile (B) from $95: 5 \%$ (A : B, 0 min), $55: 45 \%$ (A : B, $60 \mathrm{~min}$ ) with the flow rate of $12 \mathrm{~mL} / \mathrm{min}$ at $280 \mathrm{~nm}$ to yield pure compounds $1\left(5.0 \mathrm{mg}, t_{\mathrm{R}} 38.5 \mathrm{~min}\right), 2\left(4.8 \mathrm{mg}, t_{\mathrm{R}} 42.8 \mathrm{~min}\right)$ and $3\left(3.6 \mathrm{mg}, t_{\mathrm{R}} 45.7 \mathrm{~min}\right)$, respectively (Figure 1$)$.<smiles>CC(=O)C1(O)CC(O)C(O)C(C(=O)/C=C/c2ccc(O)c(O)c2)O1</smiles>

1<smiles>O=C(/C=C/c1ccc(O)c(O)c1)OC1CC(O)(C(=O)O)CC(O)C1O</smiles>

2

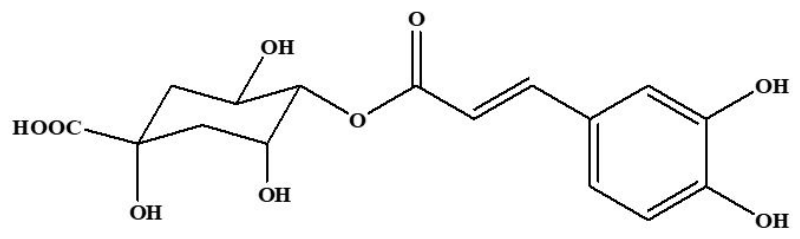

3

Figure 1. Chemical structures of compounds 1-3 isolated from E. japonica. (1: 5-Caffeoylquinic acid, 2: 3-Caffeoylquinic acid and 3: 4-Caffeoylquinic acid).

\subsection{HPLC analysis and determination of compounds 1-3}

5-Caffeoylquinic acid (5-CQA, Neochlorogenic acid, 1) amorphous powder; ESI/MS $(\mathrm{m} / \mathrm{z}): 353[\mathrm{M}-\mathrm{H}]^{-}\left(\mathrm{C}_{16} \mathrm{H}_{18} \mathrm{O}_{9}\right)$; ${ }^{1} \mathrm{H}-\mathrm{NMR}\left(600 \mathrm{MHz}, \mathrm{D}_{2} \mathrm{O}\right): \delta 7.42(1 \mathrm{H}, \mathrm{d}, \mathrm{J}=16.5 \mathrm{~Hz}), 7.00$ $(1 \mathrm{H}, \mathrm{bs}), 6.92(1 \mathrm{H}, \mathrm{bs}), 6.78(1 \mathrm{H}, \mathrm{bs}), 6.16(1 \mathrm{H}, \mathrm{d}, \mathrm{J}=16.5 \mathrm{~Hz})$, $5.17(1 \mathrm{H}, \mathrm{bs}), 4.13(1 \mathrm{H}, \mathrm{bs}), 3.75(1 \mathrm{H}, \mathrm{bs}), 2.11(2 \mathrm{H}, \mathrm{m}), 1.98$ $(2 \mathrm{H}, \mathrm{m}) ;{ }^{13} \mathrm{C}-\mathrm{NMR}\left(125 \mathrm{MHz}, \mathrm{D}_{2} \mathrm{O}\right): \delta 177.9\left(\mathrm{C}-7^{\prime}\right), 168.6(\mathrm{C}-9)$, 146.9 (C-4), 146.0 (C-7), 144.0 (C-3), 126.7 (C-1), 122.6 (C-6), 115.9 (C-5), 114.9 (C-8), 114.2 (C-2), $75.2\left(\mathrm{C}-1^{\prime}\right), 71.6$ (C-4'), 70.6 (C-3'), 71.6 (C-4'), 69.4 (C-5'), 36.8 (C-6'), 36.5 (C-2').

3-caffeoylquinic acid (3-CQA, Chlorogenic acid, 2) amorphous powder; ESI/MS (m/z) : $355[\mathrm{M}+\mathrm{H}]^{+}\left(\mathrm{C}_{16} \mathrm{H}_{18} \mathrm{O}_{9}\right)$; ${ }^{1} \mathrm{H}-\mathrm{NMR}\left(600 \mathrm{MHz}, \mathrm{D}_{2} \mathrm{O}\right): \delta 7.46\left(1 \mathrm{H}, \mathrm{dd}, \mathrm{J}=19.1,6.5, \mathrm{H}-3^{\prime}\right)$, $7.02\left(1 \mathrm{H}, \mathrm{dd}, \mathrm{J}=6.3,2.4, \mathrm{H}-5^{\prime}\right), 6.97\left(1 \mathrm{H}, \mathrm{m}, \mathrm{H}-9^{\prime}\right), 6.74(1 \mathrm{H}$, dd, $\left.J=9.6,6.5, H-8^{\prime}\right), 6.22\left(1 \mathrm{H}, \mathrm{dd}, \mathrm{J}=19.1,6.3, \mathrm{H}-2^{\prime}\right), 5.18$ $(1 \mathrm{H}, \mathrm{m}, \mathrm{H}-5), 3.92(1 \mathrm{H}, \mathrm{dd}, \mathrm{J}=13.2,4.8, \mathrm{H}-4), 1.90 \sim 1.61(4 \mathrm{H}$, m, H-2a, 2b, 6a, 6b); ${ }^{13} \mathrm{C}-\mathrm{NMR}\left(125 \mathrm{MHz}, \mathrm{D}_{2} \mathrm{O}\right), \delta 178.5$ (C-7), 166.6 (C-1'), 148.7 (C-7'), 145.9 (C-6'), 145.3 (C-3'), 126.0 (C-4'), 121.7 (C-9'), 116.2 (C-8'), 115.2 (C-2'), 114.9 (C-5'), 79.3 (C-1), 72.9 (C-4), 70.9 (C-3), 38.7 (C-2), 39.4 (C-6).

4-Caffeoylquinic acid (4-CQA, Cryptochlorogenic acid, 3) - amorphous powder; ESI/MS (m/z): $353[\mathrm{M}-\mathrm{H}]^{-}\left(\mathrm{C}_{16} \mathrm{H}_{18} \mathrm{O}_{9}\right)$; ${ }^{1} \mathrm{H}-\mathrm{NMR}\left(600 \mathrm{MHz}, \mathrm{D}_{2} \mathrm{O}\right): \delta 7.46(1 \mathrm{H}, \mathrm{d}, \mathrm{J}=20.4 \mathrm{~Hz}), 6.96$ $(1 \mathrm{H}, \mathrm{bs}), 6.90(1 \mathrm{H}, \mathrm{d}, \mathrm{J}=9.6 \mathrm{~Hz}), 6.75(1 \mathrm{H}, \mathrm{d}, \mathrm{J}=9.6 \mathrm{~Hz})$, 
$6.22(1 \mathrm{H}, \mathrm{d}, \mathrm{J}=20.4 \mathrm{~Hz}), 4.78(1 \mathrm{H}, \mathrm{dd}, \mathrm{J}=10.3,3.0 \mathrm{~Hz}), 4.22$ (1H, bs), $2.13(2 \mathrm{H}, \mathrm{m}), 1.98(2 \mathrm{H}, \mathrm{m}) ;{ }^{13} \mathrm{C}-\mathrm{NMR}(125 \mathrm{MHz}$, $\left.\mathrm{D}_{2} \mathrm{O}\right): \delta 177.7$ (C-7’), 168.6 (C-9), 146.9 (C-4), 146.3 (C-7), 144.0 (C-3), 126.7 (C-1), 122.6 (C-6), 115.9 (C-5), 114.9 (C-8), 113.8 (C-2), 77.1 (C-4'), 75.1 (C-1'), 67.6 (C-3’), 64.2 (C-5’), 39.9 (C-6'), 36.6 (C-2').

\subsection{Standard solutions}

Accurately weighed amounts of the standard compounds (1: 5-Caffeoylquinic acid, 2: 3-Caffeoylquinic acid and 3: 4-Caffeoylquinic acid) mixed and dissolved in distilled water, to obtain a stock solution of $1,000 \mu \mathrm{g} / \mathrm{mL}$. This stock solution was serially diluted to prepare working standard solutions at 10, 20, 40, 60 and $80 \mu \mathrm{g} / \mathrm{mL}$.

\subsection{Sample preparation}

The E. japonica leaves on different ethanol solvent concentration (Hot water, 20\% E, 40\% E, 60\% E, 80\% E, 100\% E) extraction were extracted with $10 \mathrm{vol}(\mathrm{v} / \mathrm{w})$ using a heating mantle at $100^{\circ} \mathrm{C}$ for $4 \mathrm{hr}$. After centrifugation, the supernatant was sample was filtered through a $0.45 \mu \mathrm{M}$ membrane filter (0.45 $\mu \mathrm{M}$, Hyundaimicro Co., Ltd, Seongnam, Korea) and then injected to the HPLC.

\subsection{HPLC analysis}

The HPLC analysis was carried out on SHISEIDO CAP CELL PAK $(4.6 \times 250 \mathrm{~mm}$, Tokyo, Japan) column (Agilent Technology, CA, USA). The HPLC conditions were column temperature of $25^{\circ} \mathrm{C}$, sample injection volume of $10 \mu \mathrm{g} / \mathrm{mL}$, flow late of $1 \mathrm{~mL} / \mathrm{min}, \mathrm{UV}$ wavelength of $280 \mathrm{nM}$. The mobile phase consisting of $0.1 \%(\mathrm{v} / \mathrm{v})$ formic acid in water $(\mathrm{A})$ and acetonitrile (B) was flooded with gradient elution 0 min, $5 \%$ B; 0-10 min, 5\% B; 10-40 min, 15\% B; 40-60 100\% B.

\subsection{Validation of the HPLC method}

The HPLC-DAD method was validated based on the guidance of the International Conference on Harmonization (ICH) for the following parameters: linearity, limits of detection and quantification (LOD and LOQ), accuracy, precision and recovery.

\subsection{Specificity (selectivity)}

The standard peaks were well-separated by the analysis of chromatograms of the sample solution and the mixed standard solution at the same retention time. This resolution was calculated using Agilent 1100 software (version 1, Agilent, Milford, MA, USA).

\subsection{Linearity, Limits of Detection (LOD) and Quantitation (LOQ)}

Linearity is the ability to obtain linear measurements within a range in proportion to the concentration of the standard compounds. The standard curves were obtained in the range of $10-80 \mu \mathrm{g} / \mathrm{mL}$ for standard compounds (1-3) at five different concentrations $(n=3)$, respectively. The standard compounds were used to calculate the linear regression equation and correlation coefficient $\left(\mathrm{R}^{2}\right)$. The LOD and LOQ were estimated at the lowest concentration injected $\mathrm{S} / \mathrm{N} \geq 3.3$ and 10 by signalto-noise ration $(\mathrm{S} / \mathrm{N})$ of standard compounds (1-3), respectively. where $\sigma$ is the standard deviation (SD) and $S$ is the slope of the regression equation (Equations 1 and 2).

$$
L O D=3.3 \times \sigma / S
$$

$L O Q=10.0 \times \sigma / S$

\subsection{Accuracy, precision and recovery}

Accuracy and precision were assessed by recovery tests performed by three different levels $(10,40$ and $80 \mu \mathrm{g} / \mathrm{mL})$ of the standard compounds (1-3). For the precision results, intra-day and inter-day assay was expressed as the relative standard deviation (RSD) of the replicate quantitative analysis of compounds (1-3). Recovery was determined by analyzing the peak areas using six determinations at $40 \mu \mathrm{g} / \mathrm{mL}$.

\subsection{Content}

We calculated the contents of standard 3-CQA, 4-CQA, and 5-CQA from the extracts of E. japonica leaves on different ethanol concentration (Hot water, $20 \%$ E, $40 \%$ E, 60\% E, $80 \%$ $\mathrm{E}$ and $100 \% \mathrm{E}$ ) extraction solvent using the linear regression equation.

\subsection{Statistical analysis}

All samples were analyzed in triplicate, and experiments were repeated three times. Statistical analysis of the data was performed with Excel software.

\section{Results and discussion}

\subsection{Structure of the identification compounds}

Compound 1 is ${ }^{1} \mathrm{H}$ and ${ }^{13} \mathrm{C}$ NMR spectra indicated for the presence of one caffeoyl and one quinic acid moiety. The ${ }^{13} \mathrm{C}-\mathrm{NMR}$ spectrum showed the presence of sixteen carbon atoms, including two carbonyl groups at $\delta 177.9$ and $\delta 168.6$, corresponding to carbons 7' and 9, respectively; two aromatic carbons bonded to hydroxyl groups at $\delta 146.9$ and $\delta 146.0$ identified as C4 and C7; two olefinic carbons at $\delta 144.0$ and $\delta 114.2$ corresponding to $\mathrm{C} 3$ and $\mathrm{C} 2$; four aromatic carbons assigned to C1, C8, C5, and C6 at $\delta 126.7, \delta 114.9, \delta 115.9$,and $\delta 122.6$, respectively; three carbons bonded to hydroxyl groups at $\delta 75.2, \delta 70.6$ and $\delta 71.6$ identified as C1', C3', and C4'; one carbon bonded to an ester group at $\delta 69.4$ attributed to $\mathrm{C}^{\prime}$; and two methylene identified as C6' and C2' at $\delta 36.8$ and $\delta 36.5$, respectively. The ${ }^{1} \mathrm{H}-\mathrm{NMR}$ spectrum displayed two ortho-coupled doublets each for $1 \mathrm{H}$, at $\delta$ 7.42 and $\delta 6.16$, and a broad singlet for $1 \mathrm{H}$ at $\delta 7.00$, confirming the presence of a tri-substituted aromatic ring and two doublets, each for $1 \mathrm{H}$, at $\delta 6.92$ and 6.78 , indicating the presence of transdi-substituted ethylene moiety in the molecule. Based on these data, compound 1 was identificatied as 5-Caffeoylquinic acid (5-CQA, Neochlorogenic acid) by comparing their reported literatures (Park, 2013; Nakatani et al., 2000). 
Compound 2 is attributed to quinic acid with the molecular formulae $\mathrm{C}_{16} \mathrm{H}_{18} \mathrm{O}_{9}$. Compound 2 showed similar signals to those of the authentic chlorogenic acid. 5-caffeoylquinic acid had the caffeoyl group attached to carbon 3 , and the $\mathrm{OH}$ groups at carbons 1, 4, and 5. We thus conclude that compound 2 is 5 -caffeoylquinic acid. The $1 \mathrm{H}$ NMR spectrum is in accordance with a phenylpropanoid, showing the characteristic signals due to two trans olefinic protons ( $1 \mathrm{H}$ each, $\mathrm{d}, \mathrm{J}=15.9 \mathrm{~Hz}$ at 7.46, $\mathrm{H}-3^{\prime}$ and 6.22 , dd, $\left.\mathrm{J}=19.1 \mathrm{~Hz}, \mathrm{H}-2^{\prime}\right)$. In addition, three aromatic protons at $7.02(1 \mathrm{H}, \mathrm{dd}, \mathrm{J}=6.3 \mathrm{~Hz})$, and $6.74(1 \mathrm{H}, \mathrm{dd}$, $\mathrm{J}=9.6 \mathrm{~Hz}$ ) correspond to the aromatic ring of chlorogenic acid, respectively. Other signals were detected close to those of chlorogenic acid. From these spectral data, compound 2 was elucidated 3-caffeoylquinic acid (3-CQA, Chlorogenic acid) with those of previously reported literatures (Park, 2013).

Compound 3 are ${ }^{1} \mathrm{H}$ and ${ }^{13} \mathrm{C}$ NMR spectra indicated for the presence of one caffeoyl group and one quinic acid moiety. The connection of the caffeoyl group and the quinic acid moiety was deduced by the chemical shifts and coupling constants of $4.78(1 \mathrm{H}, \mathrm{dd}, \mathrm{J}=10.3,3.0 \mathrm{~Hz}), 4.22(1 \mathrm{H}, \mathrm{bs})$ and $2.13(2 \mathrm{H}, \mathrm{m})$ of the quinic acid moiety reported in the literature. The NMR spectra of Compound 3 showed the signals of caffeic acid and two methylenes, one oxygen bearing carbon with acid ascribable to cyclopolyoxycarboxylic acid and quinic acid, respectively. It was identified 4-caffeoylquinic acid (4-CQA, Cryptochlorogenic acid) based on this data with those reported in previous literatures (Park, 2013; Nakatani et al., 2000).

\subsection{HPLC method validation}

The optimizes HPLC method was validated by specificity, linearity, LOD, LOQ, precision, accuracy and recovery according to the Korean Food and Drug Administration 2015 and guidelines of the International Conference on Harmonization of Technical Requirements for Registration of Pharmaceuticals for Human Use (ICH) 2014.

\subsection{Optimized HPLC condition}

To optimize the simultaneous determination of the standard compounds (3-CQA, 4-CQA and 5-CQA), analytical conditions were established by considering the parameter of the various mobile phase (A: Water, B: Acetonitrile), gradient elution, column temperature and UV wavelengths.

\subsection{Specificity (selectivity)}

No interfering peaks were confirmed in chromatograms of the standard mixture compared with the sample extract at the same retention time (Figure 2). Therefore, the results showed that the standard is correctly present in the sample extract (Table 1 ).
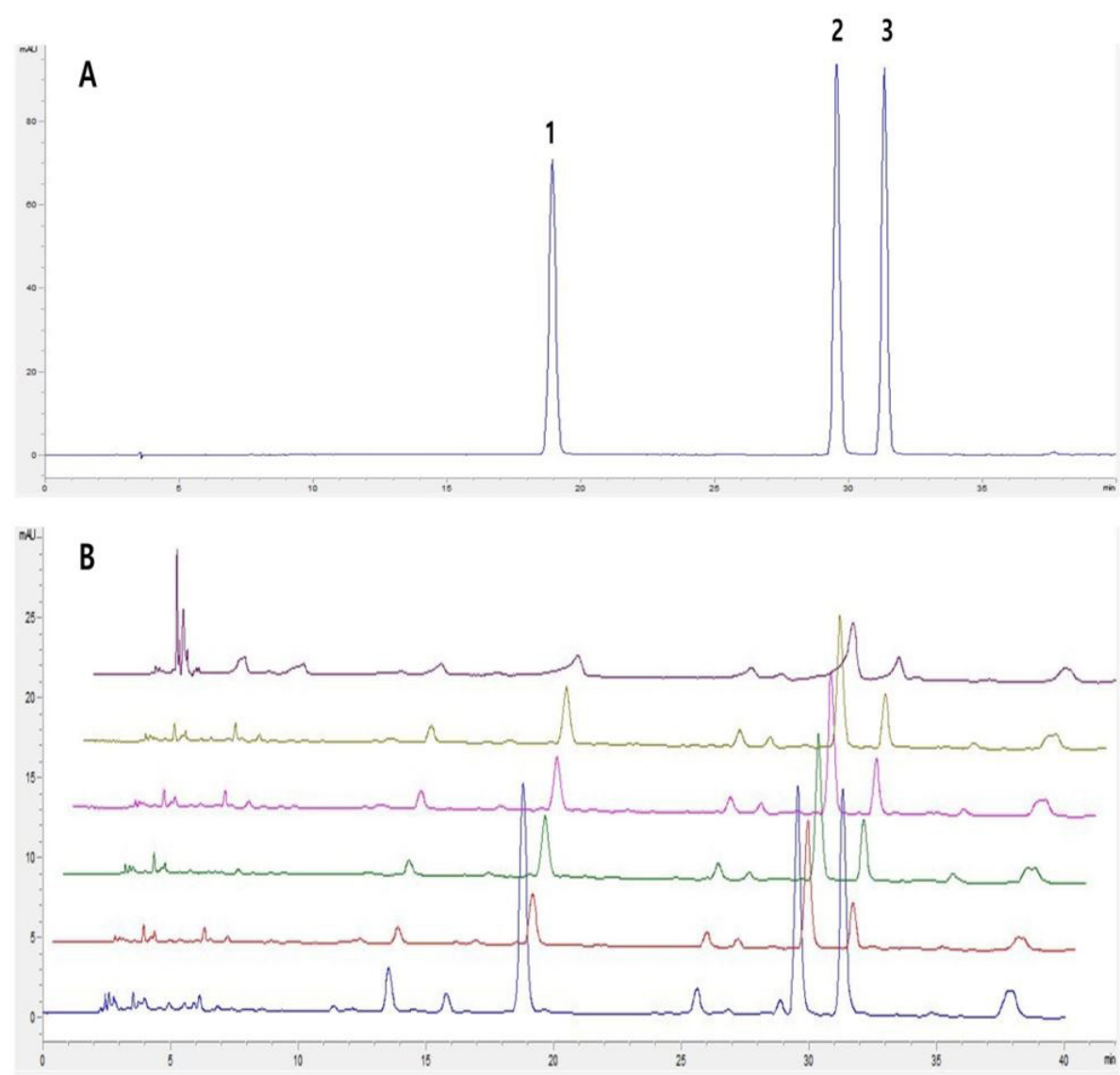

Figure 2. Specificity HPLC chromatograms of mixture standard compounds A and E. japonica extract B (1: 5-Caffeoylquinic acid, 2: 3-Caffeoylquinic acid and 3: 4-Caffeoylquinic acid). 


\subsection{Linearity and sensitivity}

Standard stock solution $(1000 \mu \mathrm{g} / \mathrm{mL})$ was prepared by dissolving the standard compound in Methanol. The stock solution was diluted at $10-80 \mu \mathrm{g} / \mathrm{mL}$ concentration. All the standards were evaluated in triplicate and the concentration of five-point levels of each point of the calibration curves was the average of all three peak areas. The regression correlation coefficent showed $\mathrm{R}^{2}$ from 0.9996 to 0.9999 in all validation runs. The LOD values was determined as $0.245,0.334$ and $0.112 \mu \mathrm{g} / \mathrm{mL}$ for all standard compounds $1-3$, respectively. Also, the LOQ values of standard compounds 1-3 were shown from values ranging from $0.741 \mu \mathrm{g} / \mathrm{mL}, 1.043 \mu \mathrm{g} / \mathrm{mL}$ and $0.340 \mu \mathrm{g} / \mathrm{mL}$, respectively (Table 1 ).

\subsection{Accuracy, precision, and recovery}

The precision of the optimized method from standard compounds was verified in three concentrations (10, 40 and $80 \mu \mathrm{g} / \mathrm{mL}$ ) of by HPLC inter-day and intra-day variation, 6 times respectively. As shown in Table 2, for standard compounds 1-3, the relative standard deviations (RSD) of the intra- and inter-day precision were shown over $0.07-0.52 \%$ and $0.00-0.8 \%$, respectively. The accuracy of three standard compounds were assessed to be within the ranges of $0.07-0.52 \%$ as the measure of RSD values. The recovery rate of standard compounds $1-3$ were calculated at three different spiked amount levels $(9.54,38.15$ and $76.30 \mu \mathrm{g} / \mathrm{mL})$ and range of recovery of three compounds was $95.6-102.3 \%$ with RSD values less than $0.4 \%$. 95.6-102.3\% stands for accuracy (Table 3). Therefore, the HPLC-DAD Method was used as validation for the simultaneous determination of phenolic compounds in E. japonica.

\subsection{Application of the method}

The developed HPLC method was applied to determine the 3-CQA, 4-CQA and 5-CQA contents with those obtained by injecting standards in the same conditions about six samples from the E. japonica leaves on different ethanol solvent concentration (Hot water, 20\% E, 40\% E, 60\% E, 80\% E and 100\% E) extraction. The results of qualitative and quantitative analyses of 3-CQA, 4-CQA and 5-CQA isolated from the extracts of E. japonica leaves on different ethanol concentration are presented in Table 4 . The 3-CQA, 4- CQA and 5- CQA were all detected in Hot water, $20 \%$ E, 40\% E, 60\% E, 80\% E and 100\% E, respectively. The content of standard 3-CQA, 4- CQA and 5- CQA compounds were evaluated in the range of $3.60-14.48 \mu \mathrm{g} / \mathrm{mL}$ (Table 4). The 3-CQA, 4- CQA and 5- CQA compound had the highest content of E. japonica leaves in Hot water and $40 \% \mathrm{E}$.

Therefore, polyphenol is one of antioxidants that protect DNA, proteins and enzymes damaged by oxygen free radicals, and has recently received attention due to its biological and various pharmacological effects. Chlorogenic acid one of a representative compound of polyphenols is a natural compound and is known as a major active ingredient in E. japonica leaves. Also, this plant has been reported to have anti-inflammatory, antioxidant and antiviral effects (Bucak et al., 2019; Naveed et al., 2018). Especially, chlorogenic acid, cryptochlorogenic acid, neochlorogenic acid has been focused on regulate fat metabolism and glucose with antioxidant activity and various physiological activities (Khanduja et al., 1999; Lee et al., 2004; Shin et al., 2012; Naveed et al., 2018). The current study was developed a method for the extraction, isolation, and identification of three phenolic compounds from E. japonica leaves. The HPLC-DAD method was validated and found to be reproducible. This study will facilitate further research on bioactive, nutritional, and medicinal compounds in E. japonica leaves. The development of this HPLC-DAD method for determination of 3-CQA, 4- CQA, and 5- CQA from E. japonica leaves could be applied for quality control of $E$. japonica leaves production and would add value

Table 1. Analytical data of regression equation, limit of detection (LOD) and limit of quantitation (LOQ) for compounds 1-3.

\begin{tabular}{cccccc}
\hline Compounds & Retention time & Regression equation & \multicolumn{1}{c}{$\mathrm{R}^{2}$} & $\mathrm{LOD}(\mu \mathrm{g} / \mathrm{mL})$ & 0.245 \\
$\mathrm{LOQ}(\mu \mathrm{g} / \mathrm{mL})$ \\
\hline 5-CQA (1) & 19.227 & $\mathrm{y}=16.629 \mathrm{x}+4.275$ & 0.9999 & 0.334 & 0.741 \\
3-CQA (2) & 29.776 & $\mathrm{y}=19.463 \mathrm{x}+11.4613$ & 0.9996 & 0.112 & 1.043 \\
4-CQA (3) & 31.562 & $\mathrm{y}=18.531 \mathrm{x}+4.439$ & 0.9999 & 0.340 \\
\hline
\end{tabular}

Table 2. Precision result of compounds 1-3 in different concentrations.

\begin{tabular}{|c|c|c|c|c|c|}
\hline \multirow{2}{*}{ Compound } & \multirow{2}{*}{ Concentration } & \multicolumn{2}{|c|}{ Intra-day ${ }^{1)}$} & \multicolumn{2}{|c|}{ Inter-day $^{2)}$} \\
\hline & & Mean $\pm \mathrm{SD}^{3)}(\mu \mathrm{g} / \mathrm{mL})$ & $\mathrm{RSD}^{4)}(\%)$ & Mean $\pm \mathrm{SD}(\mu \mathrm{g} / \mathrm{mL})$ & RSD (\%) \\
\hline \multirow{3}{*}{ 5-CQA (1) } & 9.54 & $9.53 \pm 0.05$ & 0.52 & $9.51 \pm 0.00$ & 0.00 \\
\hline & 38.15 & $38.27 \pm 0.14$ & 0.36 & $37.70 \pm 0.10$ & 0.26 \\
\hline & 76.30 & $76.15 \pm 0.34$ & 0.44 & $75.13 \pm 0.24$ & 0.31 \\
\hline \multirow{3}{*}{ 3-CQA (2) } & 9.54 & $9.15 \pm 0.03$ & 0.32 & $9.20 \pm 0.08$ & 0.86 \\
\hline & 38.15 & $38.96 \pm 0.06$ & 0.15 & $38.23 \pm 0.11$ & 0.28 \\
\hline & 76.30 & $75.91 \pm 0.28$ & 0.36 & $75.24 \pm 0.12$ & 0.15 \\
\hline \multirow{3}{*}{ 4-CQA (3) } & 9.54 & $9.40 \pm 0.01$ & 0.10 & $9.37 \pm 0.02$ & 0.21 \\
\hline & 38.15 & $38.47 \pm 0.03$ & 0.07 & $39.77 \pm 0.02$ & 0.05 \\
\hline & 76.30 & $76.51 \pm 0.15$ & 0.19 & $75.04 \pm 0.04$ & 0.05 \\
\hline
\end{tabular}

1) Intra-day: three time per day; 2 ) Inter- day: one time analysis of compounds 1-3 per day for 3 days; 3 ) Values are mean \pm standard deviation in triplicate ( $\mathrm{n}=6$ ); 4 ) Relative standard deviation. 
Table 3. Accuracy result of compounds 1-3 in different concentrations.

\begin{tabular}{|c|c|c|c|c|}
\hline Compound & Spiked amount $(\mu \mathrm{g} / \mathrm{mL})$ & Measured amount $(\mu \mathrm{g} / \mathrm{mL})$ & $\operatorname{RSD}(\%)$ & Recovery (\%) \\
\hline \multirow{10}{*}{ 5-CQA } & & & & 99.9 \\
\hline & 9.54 & $9.59 \pm 0.05$ & 0.52 & 100.9 \\
\hline & & & & 100.8 \\
\hline & & & & 99.9 \\
\hline & 38.15 & $38.27 \pm 0.14$ & 0.36 & 100.6 \\
\hline & & & & 100.5 \\
\hline & & & & 99.6 \\
\hline & 76.30 & $76.15 \pm 0.34$ & 0.44 & 99.5 \\
\hline & & & & 100.3 \\
\hline & & & & 95.6 \\
\hline \multirow{8}{*}{ 3-CQA } & 9.54 & $9.15 \pm 0.03$ & 0.32 & 96.1 \\
\hline & & & & 96.1 \\
\hline & & & & 102.0 \\
\hline & 38.15 & $38.96 \pm 0.06$ & 0.15 & 102.3 \\
\hline & & & & 102.1 \\
\hline & & & & 99.6 \\
\hline & 76.30 & $75.91 \pm 0.28$ & 0.36 & 99.1 \\
\hline & & & & 99.8 \\
\hline \multirow{9}{*}{ 4-CQA } & & & & 98.3 \\
\hline & 9.54 & $9.40 \pm 0.01$ & 0.10 & 98.6 \\
\hline & & & & 98.6 \\
\hline & & & & 100.8 \\
\hline & 38.15 & $38.47 \pm 0.03$ & 0.07 & 100.8 \\
\hline & & & & 100.9 \\
\hline & & & & 100.3 \\
\hline & 76.30 & $76.51 \pm 0.15$ & 0.19 & 100.1 \\
\hline & & & & 100.5 \\
\hline
\end{tabular}

Table 4. Contents of compounds 1-3 of E. japonica Lindl.

\begin{tabular}{crrc}
\hline \multicolumn{2}{c}{ Compound } & $\begin{array}{c}\text { Content }(\mu \mathrm{g} / \mathrm{mL} \\
\text { of extract) }\end{array}$ & RSD (\%) \\
\hline \multirow{3}{*}{ Hot Water } & 5-CQA & $7.82 \pm 0.02$ & 0.23 \\
& 3-CQA & $12.20 \pm 0.06$ & 0.52 \\
\multirow{2}{*}{$20 \% \mathrm{E}$} & 4-CQA & $12.58 \pm 0.11$ & 0.87 \\
& 5-CQA & $3.60 \pm 0.02$ & 0.61 \\
\multirow{4}{*}{$40 \% \mathrm{E}$} & 3-CQA & $9.28 \pm 0.01$ & 0.08 \\
& 4-CQA & $4.27 \pm 0.04$ & 0.98 \\
& 5-CQA & $4.68 \pm 0.04$ & 0.75 \\
$60 \% \mathrm{E}$ & 3-CQA & $14.48 \pm 0.06$ & 0.42 \\
& 4-CQA & $7.02 \pm 0.09$ & 1.24 \\
& 5-CQA & $4.29 \pm 0.05$ & 1.13 \\
$80 \% \mathrm{E}$ & 3-CQA & $10.60 \pm 0.00$ & 0.03 \\
& 4-CQA & $4.78 \pm 0.03$ & 0.55 \\
& 5-CQA & $4.18 \pm 0.03$ & 0.74 \\
\multirow{2}{*}{$100 \% \mathrm{E}$} & 3-CQA & $10.00 \pm 0.01$ & 0.14 \\
& 4-CQA & $4.39 \pm 0.01$ & 026 \\
& 5-CQA & $4.54 \pm 0.04$ & 0.97 \\
& 3-CQA & $7.82 \pm 0.02$ & 0.23 \\
& 4-CQA & $3.74 \pm 0.02$ & 0.40 \\
\hline
\end{tabular}

to the final product. The compounds 1-3 contents of Hot water and $40 \%$ E extract were $7.82-12.58$ and $4.68-14.48 \mu \mathrm{g} / \mathrm{mL}$, respectively.
In conclution, this study provides scientific basis for the extraction conditions considering phenolic ingredient content for E. japonica leaves known to have various antioxidant activities according to various ethanol concentration (Hot water, 20\% E, $40 \%$ E, $60 \%$ E, $80 \%$ E and 100\% E) extraction. Therefore, E. japonica leaves will show potential and economic value because it is used in antioxidant functional foods and anti-aging cosmetic raw materials as well as medicines. In addition, the HPLC-DAD method was developed and validated for the simultaneous determination of the major compounds (3-CQA, 4-CQA and 5-CQA) in E. japonica leaves extracts. It will be applied to the developed methods for the simultaneous quantitative analysis such as health foods, medicines, and cosmetics ingredients using E. japonica leaves.

\section{Ethical approval}

This article does not contain any studies with human participants or animals performed by any of the authors.

\section{Conflict of interest}

The authors declare that they have no conflict of interest.

\section{References}

Bae, Y. I., Chung, Y. C., \& Shim, K. H. (2002). Antimicrobial and antioxidant activities of various solvent extract from different 
parts of loquat (Eriobotrya japonica Lindl.). Korean Journal of Food Preservation, 9(1), 97-101.

Bae, Y. I., Jeong, C. H., \& Shim, K. H. (2005). Antioxidative and antimicrobial activity of epicatechin isolated from leaves of loquat (Eriobotrya japonica). The Korean Society of Food Science and Nutrition, 10(2), 118-121. http://dx.doi.org/10.3746/jfn.2005.10.2.118.

Banno, N., Akihisa, T., Tokuda, H., Yasukawa, K., Taguchi, Y., Akazawa, H., Ukiya, M., Kimura, Y., Suzuki, T., \& Nishino, H. (2005). Antiinflammatory and antitumor-promoting effect of the triterpene acid from the leaves of Eriobotrya japonica. Biological \& Pharmaceutical Bulletin, 28(10), 1995-1999. http://dx.doi.org/10.1248/bpb.28.1995. PMid:16204964.

Bucak, M. N., Bodu, M., Başpinar, N., Güngör, Ş., İli, P., Acibaeva, B., Topraggaleh, T. R., \& Dursun, Ş. (2019). Influence of ellagic acid and ebselen on sperm and oxidative stress parameters during liquid preservation of ram semen. Cell Journal, 21(1), 7-13. PMid:30507083.

Chen, J., Li, W. L., Wu, J. L., Ren, B. R., \& Zhang, H. Q. (2008). Hypoglycemic effects of a sesquiterpene glycoside isolated from leaves of loquat (Eriobotrya japonica (Thunb.) Lindl.). Phytomedicine, 15(1-2), 98-102. http://dx.doi.org/10.1016/j.phymed.2006.12.014. PMid:17291739.

Choi, Y. M., Kim, M. H., Shin, J. J., Park, J. M., \& Lee, J. S. (2003). The antioxidant activities of the some commercial teas. The Korean Society of Food Science and Nutrition, 32(5), 723-727. http://dx.doi. org/10.3746/jkfn.2003.32.5.723.

Ding, C., Chachin, K., Ueda, Y., Imahori, Y., \& Wang, C. Y. (2001). Metabolism of phenolic compounds during loquat fruit development. Journal of Agricultural and Food Chemistry, 49(6), 2883-2888. http:// dx.doi.org/10.1021/jf0101253. PMid:11409982.

Eom, H. J., Kim, S. M., Pyo, B. S., \& Lee, K. I. (2009). Changes of physiological activity by drying temperature in leaf of Eriobotrya japonica. Korean Journal of Pharmacognosy, 40(3), 178-183.

Ham, H. S., Lee, S. Y., Lee, D. W., Seong, J. W., Kim, H. S., Kim, D. S., \& Lee, Y. G. (2012). Isolation and identification of antioxidnat compound of various solvents extracted from Eribotrya japonica leaves. Journal of Life Science, 22(9), 1166-1172. http://dx.doi. org/10.5352/JLS.2012.22.9.1166.

Hwang, Y. G., Lee, J. J., Kim, A. R., \& Lee, M. Y. (2010). Chemical components and antioxidative effects of Eriobotrya japonica Lindl. Leaf. Journal of Life Science, 20(11), 1625-1633. http://dx.doi. org/10.5352/JLS.2010.20.11.1625.

Ito, H., Kobayashi, E., Takamatsu, Y., Li, S. H., Hatano, T., Sakagami, H., Kusama, K., Satoh, K., Sugita, D., Shimura, S., Itoh, Y., \& Yoshida, T. (2000). Pholyphenols from Eriobotrya japonica and their cytotoxicity against human oral tumor cell lines. Chemical \& Pharmaceutical Bulletin, 48(5), 687-693. http://dx.doi.org/10.1248/ cpb.48.687. PMid:10823708.

Jeong, Y. S., Jung, H. K., Youn, K. S., Kim, M. O., \& Hong, J. H. (2009). Physiological activity of the hot water extract from Eriobotrya japonica Lindl. Journal of the Korean Society of Food Science and Nutrition, 38(8), 977-982. http://dx.doi.org/10.3746/jkfn.2009.38.8.977.

Khanduja, K. L., Gandhi, R., Pathania, V., \& Syal, N. (1999). Prevention of $\mathrm{N}$-nitrosodiethylamine-induced lung tumorigenesis by ellagic acid and quercetin in mice. Food and Chemical Toxicology, 37(4), 313-318. http://dx.doi.org/10.1016/S0278-6915(99)00021-6. PMid:10418948.

Kim, H. J., Jo, C. U., Kim, T. H., Kim, D. S., Park, M. Y., \& Byun, M. W. (2006). Biological evaluation of the methanolic extract of Eriobotrya japonica and its irradiation effect. Korean Journal of Food Science Technology, 38(5), 684-690.
Kim, J. O., Jung, M. J., Choi, H. J., Lee, J. T., Lim, A. K., Hong, J. H., \& Kim, D. I. (2008). Antioxidative and biological activity of hot water and ethanol extracts from Phellinus linteus. The Korean Society of Food Science and Nutrition, 37(6), 684-690. http://dx.doi.org/10.3746/ jkfn.2008.37.6.684.

Kim, S. H., \& Shin, T. Y. (2009a). Anti-inflammatory effect of leaves of Eriobotrya japonica correlating with attenuation of p38 MAPK, ERK, and NF- $\mathrm{\kappa B}$ activation in mast cells. Toxicology In Vitro, 23(7), 12151219. http://dx.doi.org/10.1016/j.tiv.2009.07.036. PMid:19665545.

Kim, E., Kim, M. S., Rhyu, D. Y., Min, O. J., Baek, H. Y., Kim, Y. J., \& Kim, H. A. (2009b). Hypoglycemic effect of Eriobotrya japonica (E. japonica) in $\mathrm{db} / \mathrm{db}$ mice. The Korean Journal of Food and Nutrition, 22(2), 159-165.

Kim, M. S., You, M. K., Rhuy, D. Y., Kim, Y. J., Baek, H. Y., \& Kim, H. A. (2009c). Loquat (Eriobotrya japonica) extracts suppress the adhesion, migration and invasion of human breast cancer cell line. Nutrition Research and Practice, 3(4), 259-264. http://dx.doi.org/10.4162/ nrp.2009.3.4.259. PMid:20098577.

Kim, T. H., Shin, S. R., Kim, T. W., Lee, I. C., Park, M. Y., \& Jo, C. U. (2009d). A tyrosinase inhibitor isolated from the seeds of Eriobotrya japonica. Korean Journal of Food Preservation, 16(3), 435-441.

Lee, K. I., \& Kim, S. M. (2009). Antioxidative and antimicrobial activities of Eriobotyra japonica Lindl. leaf extracts. Journal of the Korean Society of Food Science and Nutrition, 38(3), 267-273. http://dx.doi. org/10.3746/jkfn.2009.38.3.267.

Lee, M. H., Son, Y. K., \& Han, Y. N. (2004). Tissue factor inhibitory sesquiterpene glycoside from Eriobotrya japonica. Archives of Pharmacal Research, 27(6), 619-623. http://dx.doi.org/10.1007/ BF02980160. PMid:15283463.

Liu, R. H. (2004). Potential synergy of phytochemicals in cancer prevention: mechanism of action. The Journal of Nutrition, 134(Suppl. 12), 34793485. http://dx.doi.org/10.1093/jn/134.12.3479S. PMid:15570057.

Louati, S., Simmonds, M. S. J., Grayer, R. J., Kite, G. C., \& Damak, M. (2003). Flavonoids from Eriobotrya japonica (Rosaceae) growing in Tunisia. Biochemical Systematics and Ecology, 31(1), 99-101. http:// dx.doi.org/10.1016/S0305-1978(02)00072-8.

Lv, H., Chen, J., Li, W. L., \& Zhang, H. Q. (2008). Studies on the triterpenes from loquat leaf (Eriobotrya japonica). Zhong Yao Cai, 31(9), 1351-1354. PMid:19180956.

Manach, C., Williamson, G., Morand, C., Scalbert, A., \& Remesy, C. (2005). Bioavailability and bioefficacy of polyphenols in humans. I. Review of 97 bioavailability studies. The American Journal of Clinical Nutrition, 81(Suppl. 1), 230-242. http://dx.doi.org/10.1093/ ajen/81.1.230S. PMid:15640486.

Nakatani, N., Kayano, S., Kikuzaki, H., Sumino, K., Katagiri, K., \& Mitani, T. (2000). Identification, quantitative determination, and antioxidative activities of chlorogenic acid isomers in Prune (Prunus domestica L.). Journal of Agricultural and Food Chemistry, 48(11), 5512-5516. http://dx.doi.org/10.1021/jf000422s. PMid:11087511.

Naveed, M., Hejazi, V., Abbas, M., Kamboh, A. A., Khan, G. J., Shumzaid, M., Ahmad, F., Babazadeh, D., Xia, F., Modarresi-Ghazani, F., Li, W., \& Zhou, X. (2018). Chlorogenic acid (CGA): a pharmacological review and call for further research. Biomedicine and Pharmacotherapy, 97, 67-74. http://dx.doi.org/10.1016/j.biopha.2017.10.064. PMid:29080460.

Park, J. B. (2013). Isolation and quantification of major chlorogenic acids in three major instant coffee brands and their potential effects on $\mathrm{H}_{2} \mathrm{O}_{2}$-induced mitochondrial membrane depolarization and apoptosis in PC-12 cells. Food \& Function, 4(11), 1632-1638. http:// dx.doi.org/10.1039/c3fo60138b. PMid:24061869. 
Park, Y. S., Park, Y. J., Kim, H. J., Im, M. H., Lee, M. K., Kim, Y. M., Cho, J. Y., \& Heo, B. G. (2008). Physiological activity of ethanol extract from the different plant parts of loquat (Eriobotrya japonica Lindl.). Weonye Gwahag Gisulji, 26(1), 75-80.

Ryu, S. W., Jin, C. W., Lee, H. S., Lee, J. Y., Sapkota, K., Lee, B. G., Yu, C. Y., Lee, M. K., Kim, M. J., \& Cho, D. H. (2006). Changes in total polyphenol, total flavonoid contents and antioxidant activities of Hibiscus cannabinus L. The Korean Society of Medicinal Crop Science, 14(5), 307-310.

Shih, C. C., Lin, C. H., \& Wu, J. B. (2010). Eriobotrya japonica improves hyperlipidemia and reverses insulin resistance in high-fat-fed mice. Phytotherapy Research, 24(12), 1769-1780. http://dx.doi.org/10.1002/ ptr.3143. PMid:20564460.

Shin, H. J., Kim, K. H., Hwang, H. R., Kim, N. Y., Kim, S. H., \& Yook, H. S. (2012). Antioxidant activities of extract fractions of leaves from loquat (Eriobotrya japonica Lindl.) by cultivars. Journal of the Korean Society of Food Science and Nutrition, 41(8), 1029-1034. http://dx.doi.org/10.3746/jkfn.2012.41.8.1029.
Sun, G., Zhang, Y., Takuma, D., Onogawa, M., Yokota, J., Hamada, A., Yoshioka, S., Kusunose, M., Miyamura, M., Kyotani, S., \& Nishioka, Y. (2007). Effect of orally administered Eriobotrya japonica seed extract on allergic contact dermatitis in rats. The Journal of Pharmacy and Pharmacology, 59(10), 1405-1412. http://dx.doi.org/10.1211/ jpp.59.10.0011. PMid:17910816.

Takuma, D., Guangchen, S., Yokota, J., Hamada, A., Onogawa, M., Yoshioka, S., Kusunose, M., Miyamura, M., Kyotani, S., \& Nishioka, Y. (2008). Effect of Eriobotrya japonica seed extract on 5-fluorouracil-induced mucositis in hamsters. Biological \& Pharmaceutical Bulletin, 31(2), 250-254. http://dx.doi.org/10.1248/bpb.31.250. PMid:18239282.

Whang, T. E., Lim, H. O., \& Lee, J. W. (1996). Anticancer effect of Eriobotrya japonica lindl. by specificity test with several cancer cell lines. Korean Journal of Medicinal Crop Science, 4(4), 314-320.

Wu, Y., Jian, T., Lv, H., Ding, X., Zuo, Y., Ren, B., Chen, J., \& Li, W. (2018). Antitussive and expectorant properties of growing and fallen leaves of loquat (Eriobotray japonica). Revista Brasileira de Farmacognosia, 28(2), 239-242. http://dx.doi.org/10.1016/j.bjp.2018.02.006. 